\title{
THE ARCTIC INSTITUTE, LENINGRAD
}

In 1945 the Arctic Research Institute at Leningrad completed twenty-five years of scientific activity. The publication of a small book ${ }^{1}$ outlining its development and giving a reminder of its most notable achievements, provides an opportunity for surveying the growth of the Institute from its modest start to its present imposing size.

Although 1920 is the year from which the Arctic Institute reckons its activity, the seeds were in fact sown the year before, when a group of scientific workers interested in the north were formed into a "Commission for the Study of the North" under the Supreme Council of National Economy. The work of this body was extremely limited, since most of the territory in which it would have worked was occupied by the country's enemies. In 1920 this Commission was placed at the disposal of the Soviet military authorities in the north, at the request of those authorities and with the sanction of Lenin, and was renamed the Northern Scientific Industrial Expedition. From co-ordinating the scientific work of various bodies under the army, this organisation's scope was soon widened to undertake, by the sending out of expeditions, the systematic study of natural resources in the far north. In 1925 the Northern Scientific Industrial Expedition became the Institute for the Study of the North, but the nature of its work remained the same. A number of expeditions were sent out every year, on land and sea, studying principally geological and hydrological problems; the area of activity was the coastal region from Murmansk to the Yenisey, and north to Novaya Zemlya. Polar stations, where small groups of scientific workers made observations all the year round, were established. In the late twenties the number of sea-going expeditions increased, and Franz Josef Land was visited and explored several times, but there was still no question of working east of the Kara Sea. The Director of the Institute at this time was Professor R. L. Samoylovich, a geologist who had been a member of the original group of scientists forming the Commission for the Study of the North in 1919. In 1930 there was another reorganisation, accompanied by a change of name; the Institute for the Study of the North became the All-Union Arctic Institute. Professor O. Yu. Shmidt, a mathematician who had led expeditions to Franz Josef Land, became Director. Deputy Directors were Professors Samoylovich and V. Yu. Vize, the latter a hydrologist and meteorologist who had been on Sedov's expedition of 1912-14 and who has been concerned with the Arctic ever since. From 1930 onwards the Institute recognised the whole length of Arctic Russia as its province, and serious attention was given to the central and eastern sectors.

A landmark in the history of Soviet Arctic development was reached in 1933, when a Government decree created the Chief Administration of the Northern

1 Za chetvert' veka. Obzor deyatel'nosti Arkticheskogo Instituta Glavsevmorputi za 25 let [For a quarter of a century. A survey of the activity of the Arctic Institute of the Chief Administration of the Northern Sea Route over 25 years], by Ya. Ya. Gakkel'. Moscow, Leningrad: Izdatel'stvo Glavsevmorputi, 1945, 109 pp., photos. 8 Roubles. 
Sea Route. This body was to "pioneer the Northern Sea Route from the White Sea to Bering Strait, equip this route, keep it in good condition and secure the safety of shipping along it". To accomplish this, the new organisation was given extremely wide powers, including responsibility for industrial and social development in all Siberia north of the 62nd parallel; and the Arctic Institute was placed under its control, as its chief scientific organ. The link between the two was strong, for Professor Shmidt became the first head of the Northern Sea Route Administration, and Professor Samoylovich succeeded him as Director of the Arctic Institute. The Institute was further expanded at this time, and was relieved of various practical commitments such as responsibility for the construction and supply of polar stations, thus facilitating concentration on their scientific direction, and for provision of ships for expeditions. It was also able to put scientific workers on board any of the Northern Sea Route Administration's ships, and so cover a much wider area than had been possible before.

By 1936 the internal organisation of the Institute had reached a considerable size and degree of complexity. At its head was the Director and three Deputy Directors. Under them worked the following departments: the geological department with sections for general geology, useful minerals and geophysics and geochemical and radio laboratories; the department of cartography and geodesy; the hydrological department, with sections for marine and river hydrology and laboratories for hydrochemistry and investigation of the sea bottom; the industrial-biological department, with sections for hunting, fishing, marine biology, economics of hunting and a taxidermy laboratory; the reindeer department, with sections for zoology, economic organisation, pasturelands and food, technology, and a chemical laboratory. Those were the main departments, and the two latter each supported a number of regional stations at local centres of their respective activities. At the headquarters of the Institute there were also a bureau for the study of the structure and mechanics of ice, a library, a bibliographical bureau, a publishing department, a photographic laboratory, an instrument workshop, an administrative department, and a Museum of the Arctic. This museum displayed various objects of interest, especially in connection with the history of exploration, and organised special arctic exhibitions in other places. A little later a shipping research department was formed. In addition it may be noted that when the Institute first came under the control of the Northern Sea Route Administration, part of the expansion then undertaken was the creation of a hydrographic department; but the quantity of work was found to be such that very shortly afterwards this department was taken from the Institute and became the hydrographic administration directly under the Chief Administration of the Northern Sea Route. By 1937 it was clear that the Institute had become a many-sided organisation covering almost every aspect of the development of the arctic regions.

Another phase, however, was initiated in 1938. In that year the Council of People's Commissars decided that the Northern Sea Route Administration must concentrate all its activities on developing the Sea Route itself; those of its functions not directly concerned with the Sea Route, including the large 
measure of responsibility for Siberia north of the 62nd parallel, passed to other authorities. In 1939 the eighteenth session of the All-Union Communist Party ordained that the Northern Sea Route was to be turned into a normally functioning waterway by the end of the current Five-Year Plan, in 1942. There may have been some connections between these decisions and the disasters at the end of the navigation season of 1937, when a number of ships were caught in an early freeze-up and were icebound for the winter, including seven out of the eight then serviceable icebreakers. About this time also the trials for treason of Bukharin and other leading Communists were causing an extensive purge of undesirables in every sphere of activity. It was to be expected, therefore, that when this lessening of scope and concentration on the Sea Route had its repercussions on the Arctic Institute there was a certain amount of recrimination still in the air. The Institute was accused of working not for the Sea Route but on unimportant scientific problems; its attempt to carry out a geological survey of the whole of the Soviet Arctic was condemned as irrelevant, its so-called show trips to high latitudes in icebreakers were pronounced a waste of time. The editors of Problemy Arktiki, one of the Institute's publications, were accused of maintaining a low level of ideals, having a non-political outlook, not concentrating on the basic problems of the conquest of the Arctic and not having a really scientific approach. At all events the Institute lost its geological and biological-industrial departments to corresponding bodies of the Northern Sea Route Administration and assumed a more exclusively hydrological and meteorological character. In 1938, before these changes took place, there was a change in the directorship. At about the same time as I. D. Papanin, of the North Polar Drift Expedition of 1937-38, succeeded O. Yu. Shmidt as head of the Northern Sea Route Administration, Professor Samoylovich was replaced as Director of the Arctic Institute by Dr P. P. Shirshov, one of Papanin's three companions of the Drift Expedition. The name of the Institute was again changed at this time to the Arctic Research Institute of the Chief Administration of the Northern Sea Route.

The predominantly hydrological and meteorological character of the Institute's work remained throughout the war. The hydrological department was considerably extended to include sections for ice research and ice forecasts; and the ice and weather service, which had been formed in 1938, grew very considerably. This latter organisation took over certain duties previously discharged by the State Hydrological Institute and the Northern Sea Route Administration's Interdepartmental Bureau of Ice-forecasting, and so became the sole ice-forecasting authority; it collated and analysed weather and ice reports from ships, aircraft and polar stations; and in 1941 or 1942 its scope was extended to cover the White Sea and the Sea of Okhotsk. Its reports became essential to activity of almost every kind in the Soviet Arctic, and by 1945 it represented possibly the most important aspect of the Institute's work. The man chiefly responsible for the work of this department was Professor Vise, who in 1946 was awarded a Stalin Prize for his work on ice forecasting. During the war the Institute also provided navigational aids and handbooks for the Soviet navy, kept up a certain amount of expeditionary work, and maintained 
the scientific direction of seventy-seven polar stations. From about 1941 the position of Director was held by Ya. S. Libin, a scientist with many years' arctic experience who had recently led an expedition to the "pole of inaccessibility" in an aircraft piloted by I. I. Cherevichny. Towards the end of the war V. Kh. Buynitski, a hydrologist who had been chief of the scientific staff on board the G. Sedov during her three years' drift from 1937 to 1940 , became Director.

About the end of the war the scope of the Arctic Institute was again enlarged. Geological and geomorphological work was once more taken up in 1945. It had been found that the geological department of the Northern Sea Route Administration, which had taken over the Institute's geological work in 1940, was concerned too much with production and industrial aspects to cope adequately with the scientific research side of the work. This was a vindication of the Institute's earlier interest in geological survey, which seven years before had been called irrelevant. About 1945, also, new departments for the study of general geography and the history of exploration were formed, and further investigations were undertaken in what is called the Moscow department of the Institute on the economic aspect of the industrial potentialities of the Northern Sea Route.

It is not the object of this outline to go into details of the field work done by members of the Institute, but no account of the Institute's growth would be complete without some indication of the extent of that work. Over the period of twenty-flve years more than 300 expeditions have been sent out, those with geological and hydrological tasks being the most numerous. Over a third of all the expeditions were geological, and their scientific results fill seventy volumes of the Transactions of the Arctic Institute out of 185 issued. Among the mines now working, which were first surveyed by Arctic Institute geologists, are the Pechora coal mines, the apatite deposits at Khibinskaya tundra in the Kola Peninsula, the Taymyr coal basin which supplies Dikson Island, the Zyryansk mines on the Kolyma River and the tin mines in the Chaun area which during the war produced more tin than all the other tin mines in the U.S.S.R. together. Besides these, which are actually in production, some 2000 ore beds were located. The hydrological expeditions have done extensive work and produced 150 papers on their results. They have recently been concentrating on the Laptev, East Siberian and Chukchi Seas. Geographical discoveries include a number of small islands, most of Severnaya Zemlya (only the east coast was seen by Vil'kitski in 1913), and the more exact placing of certain islands, especially some in Franz Josef Land. Botanical, biological and cartographical work has been done; studies have also been carried out on terrestrial magnetism and the ionosphere. It must not be thought, however, that the Arctic Institute is the only scientific body which sends expeditions north, though it probably sends the largest number. Other departments of the Chief - Administration of the Northern Sea Route send out scientific parties, particularly the Hydrographic Administration which has its own research ships, and the Research Institute of Polar Agriculture. Several bodies affiliated to the Academy of Sciences also work in the North, particularly the V. A. Obruchev Institute 
for the Study of Permanently ${ }^{-}$Frozen Soil and the Murmansk Biological Station. The State Russian Geographical Society, the State Oceanographical Institute and the State Hydrological Institute should also be mentioned.

There is no doubt that the Arctic Institute has developed during the first twenty-five years of its existence into an organisation of great experience in many aspects of scientific work in arctic regions, and of some experience in all aspects, and that nowhere else in the world is there such an organisation run on a comparable scale.

T. E. ARMSTRONG

\section{HANDBOOK FOR SOVIET POLAR WORKERS}

[Review of Spravochnaya Knizhka Polyarnika (The Polar Workers' Reference Book), by S. D. Lappo. Izdatel'stvo Glavsevmorputi (Publishing House of the Chief Administration of the Northern Sea Route), 1945, 423 pp., maps and ills. 25 Roubles.]

The author of this handbook, himself a polar worker and scientist of many years standing, has arranged the book in the main as a non-alphabetical glossary of scientific and local terms pertaining to the Arctic. He describes it as dealing with oceanography in its widest sense, including not only the hydrology of the sea, but the climatology, biology and geology of the sea and its shores. The book is written for the benefit of all polar workers, whether they be sailors, air-line ground staff or the personnel of polar stations.

The first half of the book is simply a revised edition of the author's Okeanograficheski Spravochnik Arkticheskikh Morey SSSR [Oceanographical Handbook of the Arctic Seas of the U.S.S.R.] published in Leningrad and Moscow in 1940. It contains chapters on coastal structures and relief, surface hydrology, sea-bottom relief and sea-ice. Fresh material for this book includes a section on climate, a long chapter on fauna, from protozoa to polar bears, with many illustrations, and two chapters, which are all too short, on the population of the North and administrative divisions. $A$ useful feature is the inclusion in the earlier chapters (not always, unfortunately, included in the index) of a number of local and maritime words for winds, ice formations, geographical terms and so forth. In addition the author gives as appendices such data as a table of hours of twilight at various latitudes, the Beaufort scale, details of boundaries between Arctic seas according to the International Hydrographic Bureau, and a useful though provisional list of conventional signs for maps of ice formations. There is also a fairly full bibliography.

It is interesting to compare this handbook with Stefansson's Arctic Manual (New York, 1944) written for the United States Army Air Force. The chief difference seems to be that Stefansson is writing primarily for people who have never been in the Arctic before while Lappo presupposes in his readers a certain acquaintance with it. Lappo's readers are already working in the Arctic, and he is giving them facts from which they can, if they like, find out something of what their fellow workers are doing, or find out more about the part of the world they are living in. No practical suggestions on what to wear; what to eat or how to build a snow house appear in the Russian book, while there are no illustrations of brachiopods or diagrams of fohn effect in the American. 